Environmental

Sciences and

Ecology: Current

Research (ESECR)

\author{
Volume 2 Issue 5, 2021 \\ Article Information \\ Received date: July 23, 2021 \\ Published date: August 23, 2021 \\ *Corresponding author \\ LEN Jackai, North Carolina A\&T State \\ University, 1601 East Market St., \\ Greensboro, NC 27411, USA
}

Distributed under Creative Commons CC-BY 4.0

\section{Biological and Molecular Evidence for the Existence of Bruchid Ecotypes in the Nigerian Cowpea Ecosystem}

LEN Jackai ${ }^{{ }^{*}}$, G Thottappilly ${ }^{2}$, HO Sintim ${ }^{1}$, TI Ofuya ${ }^{3}$ and BN Dingha ${ }^{1}$

${ }^{1}$ North Carolina A\&T State University, Greensboro, NC. USA

${ }^{2}$ International Institute of Tropical Agriculture, Ibadan, Nigeria

${ }^{3}$ Federal University of Technology, Akure, Nigeria

\section{Abstract}

The oviposition, growth and development of six populations of Callosobruchus maculatus (IT, PH, UM, MD-1, MD-2, MD-3) from different localities in Nigeria were studied on a resistant (TVu 2027) and susceptible (Ife Brown) cowpea cultivar and four cultivars of African yam bean, Progenies obtained by cross-mating individuals from the different populations were also studied.. Oviposition was highest in the MD insect beetle population and lowest in the UM population. IT and PH populations had the highest adult emergence and shortest development times on the resistant control. Genomic differences among bruchid populations were confirmed by the Random Amplified Polymorphic DNA (RAPD) fingerprinting technique with $\mathrm{PH}$ population being the most distant. All progenies with IT as the female parent also had better emergence and shorter development time than their reciprocal crosses or those involving other populations, but this varied with the fitness of the male parent. The UM population averaged $<10 \%$ adult emergence on TVu 2027 compared to $71.9 \%$ on the susceptible control, but was better adapted to the AYB ( $66 \%$ emergence) than were other populations. These results suggest possible existence of ecotypes, of this bruchid species in Nigeria with potentially important implications for the development and deployment of resistant cowpea varieties.

Keyword

African Yam Bean; Callosobruchus maculatus; Cowpea; Cultivar Susceptibility; Ecotypes, Nigeria

\section{Introduction}

Grain legumes suffer drastic reduction in market value and nutritional properties because of damage in storage by bruchids of the genus Callosobruchus spp. [1-4]. This genus has a pantropical distribution and includes the most important post-harvest pest species of cowpea worldwide [5-6]. Most species are multivoltine making them very destructive in storage [7]. The pest species in the genus worldwide include C. maculatus Fabricius, C. chinensis (Linnaeus), C. analis (Fabricius), C. rhodesianus (Pic), C. subinotatus (Pic), and C. phaseoli (Gyll). These species have been reported to attack cowpea [6-8], causing up to 70 $\%$ damage to seeds of susceptible cultivars after six months of storage. Although several insecticides are used to protect stored cowpea, alternative control strategies such as the use of resistant cultivars (e.g., TVu nos. 2027, 11952 and 11953, IT86D-4980), solar heating, and the use of a wide range of liquid or powdered plant extracts and various plant oils and bagging systems greatly reduced the need for synthetic insecticide use in storage $[9,10,3,11]$. Bruchid populations from different parts of the world have been shown to vary in their basic bionomics [12-14]. Various workers have also reported increased survival in different bruchid populations on the resistant cowpea, TVu 2027 [15, 1, and 16]. The bruchid populations in these studies were obtained either from different localities in the same country, or from different countries. These differences in feeding behaviour on the resistant cowpea are thought to be, at least in part, due to geographical isolation and possible adaptation to different ecological conditions [17, 12, and 18]. If this were the case, it mis possible that in a large country with wide-ranging ecological zones (Figure 1), distinct bionomic differences may be prevail among bruchid populations from widely disjointed regions. In addition, in bruchid populations attacking more than one host plant, adaptation to different defense compounds may be an important factor leading to evolution of differences between either sympatric or allopatric populations. Other workers have referred to such sub-populations as strains [12-19], biotypes [16] ecotypes (Shade et al., 1996; Tarver et al. 2006), or simply "cultures" [20-21].

Irrespective of the mechanism(s) that have given rise to new and distinctive pest populations, their existence poses a serious threat to agricultural production, and the success of newly developed resistant cultivars which may not have any pre-adaptive mechanisms to protect themselves. Cowpea resistance to $C$, maculatus has been sustained for several years, but it cannot be predicted how long it will continue to be effective because of its narrow genetic base [22]. New and more diversified resistance genes are needed to broaden the genetic base of this resistance. The search for new sources of resistance genes need not be limited to cowpea since, other plant genera can also be exploited. One of the potential sources for resistance to cowpea pests is the African yam bean, Sphenostylis stenocarpa Hochst A. Richard (Harms), an under-exploited African legume that appears to be resistant to a wide range of cowpea pests [23-24]. This legume grows in the humid forest and transition zones of West and Central Africa, and the savanna of east and southern Africa [25-26]. C. maculatus survives on some varieties of S. stenocarpa better than on others. This behaviour is common from an ecological standpoint but the interaction between C. maculatus and the African yam bean was striking. We became interested in the interaction because beetle populations from different parts of Nigeria varied drastically in their ability to survive on S. stenocarpa. This led us to investigate the extent to which this phenomenon also occurs with the same beetle species on cowpea in Nigeria, and how it affected the search for pest resistant cowpea. There is some published evidence of intra-specific variation within C. maculatus $[12,13,27,18,28,29]$. These and other studies used various techniques. In this study, we investigated the possible existence of intra-specific variation among C. maculatus from different parts of Nigeria on cowpea 


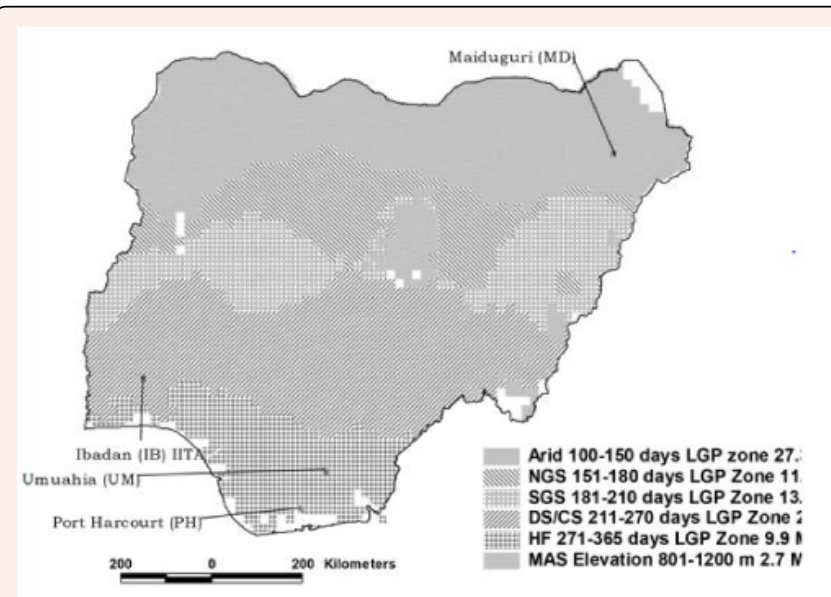

Figure 1: Agro-ecological zones of Nigeria showing collection sites of different populations of Callosobruchus maculatus.

and African yam bean hosts using biological and molecular approaches to detect small differences between populations [30-34].

\section{Materials and Methods}

Insects

C. maculatus adults and eggs laid on cowpea or African yam bean were collected from four localities in Nigeria, namely Port Harcourt [PH], Umuahia [UM], Maiduguri-1 to 3 [MD-1, MD-2, MD-3], and Ibadan (IITA-laboratory population [IT]) (Figure 1) There were three different beetle collections in the Maiduguri area at different times of the year, from different cowpea cultivars (known only as "local cowpea") in different village markets. The Maiduguri collections were treated as different beetle populations because of the proximity to the Cameroon cowpea market.. All the populations were subsequently maintained on the cowpea variety Ife Brown, following procedures described by Singh \& Jackai in the Storage Entomology Laboratory of the International Institute of Tropical Agriculture (IITA) in Ibadan, Nigeria. Ambient rearing temperature was $27 \pm 2{ }^{\circ} \mathrm{C}$ and relative humidity ranged from $70-80 \%$. Insects from the different localities are hereafter referred to as 'populations'.

\section{Beetle development on cowpea and African yam bean}

Twenty seeds each of the resistant cowpea cultivar, TVu 2027, the susceptible local cowpea cultivar (Ife Brown), and five local cultivars of African yam bean (um1, um2, um3, um4, and um5) were purchased from a local market at Umuahia (Figure 1). These were each placed in a plastic box measuring $6.5 \times 6.5 \times 2.5 \mathrm{~cm}$. There were thus five replications of each of the seven cultivars. The seeds were fumigated with aluminium phosphide pellets for $24 \mathrm{~h}$ to eliminate any concealed infestation and then left in an airy, insect-free environment for $48 \mathrm{~h}$ to dispel any residues of the fumigant. The seeds in each box were subsequently exposed for $24 \mathrm{~h}$ to one pair of newly emerged adults from the stock culture of each beetle population and ovi posited eggs were left to incubate for seven days after which they were counted. From 20 days after ovi position, the boxes with seeds were examined daily for adult emergence until 55 days after ovi position, or until the second generation, progeny started ovi positing on the susceptible cultivar.

\section{Demographic parameters of beetle progeny on TVu 2027 and Ife Brown}

Reciprocal crosses of the six beetle populations were made using insects from the laboratory culture of each population. The $\mathrm{F} 1$ adults were then kept on Ife Brown for on generation before being used in this experiment. Newly emerged adults were exposed to seeds for $24 \mathrm{~h}$ as above but using only the cultivars TVu 2027 and Ife Brown. Indices taken in the two experiments above were number of eggs laid per container, development time from oviposition to adult and percent adult emergence. An index of suitability of a substrate for insect development, Growth Index (GI), was calculated as log \% AE / TDT [35]. Where AE is the percent adult emergence and TDT is the development time. This was used to compare the F1 and reciprocal crosses

\section{Molecular differentiation of $C$. maculatus populations using RAPD markers}

DNA was isolated using a method adapted from [32]. The head capsule and prothorax of one beetle from each population were removed and placed individually in an Eppendorf tube and homogenized using a conical glass pestle. One $\mathrm{ml} \mathrm{homogenate}$ consisted of $80 \mu \mathrm{l} 0.008 \mathrm{M} \mathrm{NaCl}, 0.16 \mathrm{M}$ sucrose, $0.06 \mathrm{M}$ EDTA, $0.5 \%$ SDS, $0.1 \mathrm{M}$ Tris$\mathrm{HCl}$ buffer, $\mathrm{pH}$ 8.6. The homogenate was incubated at $65^{\circ} \mathrm{C}$ for 30 minutes and then 40 $\mu \mathrm{l}$ of potassium acetate $(8 \mathrm{M})$ was added to the final solution. This was then incubated for 30 minutes at $4^{\circ} \mathrm{C}$. Samples were centrifuged at 12000 -x g for 10 minutes at room temperature in an Eppendorf centrifuge. The supernatant was removed into a fresh tube, $100-\mu 195 \%$ ethanol added and the solution was again centrifuged at $12000 \mathrm{xg}$ for 10 minutes. The supernatant was then discarded and the pellet washed with $70 \%$ ethanol, dried and re-suspended in de-ionized water and stored at $-70{ }^{\circ} \mathrm{C}$ until used.

\section{PCR and agarose gel electrophoresis}

Oligonucleotide primers (10 mers each) tested in this study were purchased from Operon Technologies (Alamenda, Ca, USA). RAPD-PCR analysis was done using the method described by [36]. Two concentrations of each template DNA ( $24 \mu \mathrm{g}$ and $96 \mathrm{c} \mu \mathrm{g}$ per reaction) were used to test reproducibility and eliminate sporadic amplification products from the analysis. Amplifications were performed in a $25 \mu \mathrm{l}$ reaction mixture consisting of $10 \mu \mathrm{g}$ of diluted genomic DNA $(5 \mu \mathrm{l}), 2.5 \mu \mathrm{l}$ of $10 \mathrm{X}$ reaction buffer (Promega), 100 $\mu \mathrm{M}$ each of dATP, dCTP, dGTP, and dTTP, $0.2 \mathrm{mM} \mathrm{MgCl} 2,0.5 \%$ Tween- 20 and 2 units of Taq polymerase (Promega). A single primer was used in each reaction. The reaction mixture was overlaid with a drop of mineral oil to prevent evaporation. Amplification was performed in a Perkin Elmer Thermocycler, Model 9600. The cycling program: (1) one cycle at $94^{\circ} \mathrm{C}$ for 1 minute, followed by 40 cycles at $94^{\circ} \mathrm{C}$ for 1 minute and $72{ }^{\circ} \mathrm{C}$ for 1 minute; (2) one cycle at $72{ }^{\circ} \mathrm{C}$ for 5 minutes. Amplification products were maintained at $4{ }^{\circ} \mathrm{C}$ until electrophoresed. The reaction products were resolved by electrophoresis in a $1.4 \%$ agarose gel using $1 \times$ TAE buffer at 150 constant $\mathrm{V}$ for 2.5 hours. A $1 \mathrm{~kb}$ ladder (Life Technologies, Gaithersburg, MD, USA) was included as a size marker. Gels were visualized by staining with Ethidium Bromide solution $(0.5 \mu \mathrm{g} / \mathrm{ml})$ and banding patterns were photographed using a UV light and a red filter. RAPD markers that were consistently reproduced in at least two PCR reactions were taken into account for further analysis. Fragment sizes of RAPD bands were estimated from the gel photograph by comparison with the $1 \mathrm{~kb}$ ladder marker. From the whole set of reproducible RAPD bands generated in the eight populations (two more than the number used in the biological tests) by the different primers, only bright bands were considered for scoring as either present (1) or absent $(0)$. A data matrix with primers in columns and ecotypes was assembled from these scores. All DNA fragments were scored and used to estimate the Genetic Similarity Coefficients (GS) according to Jaccard (1908). This does not consider the joint absence of a marker as an indication of similarity (Sneath \& Sokal, 1973). GSxy $=a /(a+b+c)$ where; GSxy represents genetic similarity between two individuals $\mathrm{x}$ and $\mathrm{y}$; $\mathrm{a}$ indicates the number of polymorphic bands present in both individuals; $\mathrm{b}$ is the bands present in $\mathrm{x}$ but absent in $\mathrm{y}$; and $\mathrm{c}$ is the number of bands present in $\mathrm{y}$ but absent in $\mathrm{x}$. Further analysis was carried out with Unweighted Pair Group Method of Arithmetic Average (UPGMA) algorithm and a similarity dendrogram was generated from this. This was designed to group the populations into clusters based on genetic similarity.

\section{Statistical Analyses}

All data from experiments 1 and 2 were analysed using General Linear Model ANOVA, and where significant results were obtained, multiple comparisons were performed using Fisher's Protected LSD. Percentage data were arcsine transformed before analysis [37]. Comparisons of parental and progeny data were made using Chi-square analysis. Zero values were not included in any of the analyses. Primed PCR fragments were analysed using GENSTAT 5 Release 3.1 (Lawes Agricultural Trust, Rothamsted Experimental Station, Harpenden, and Hertfordshire, UK).

Results

\section{Oviposition}

Overall, without regard to the host plant (cultivar), the UM beetle population was least fecund while the ovi position levels among the other populations were generally similar. Of the other populations, MDs were the most fecund across cultivars. The MD-2 and 3 had the highest ovi position on the two cowpea cultivars. There was however, no clear-cut preference for any of the cultivars (Table 1), within the different host plants.

\section{Larval development}

Based on the development data from S. stenocarpa, we distinguished two population groups (Table 2). The first group (beetles from PH, IT, MD-1 and MD-3) completed larval development in over 30 days on the $S$. stenocarpa cultivars from Umuahia. Larvae in the other group, UM and MD-2 populations, developed faster (less than 28 days) on these same host plant genotypes. Two other groups were distinguished based on the developmental time on the resistant cowpea, TVu 2027. The first was the IT population which developed in a relatively short time (27.9 days) compared to the $\mathrm{PH}$ population 
Table 1: Mean number of eggs laid by Callosobruchus maculatus collected from Different Localities in Nigeria+ on Seeds of S. stenocarpa and Vigna unguiculata. ( $\mathrm{n}=25-50$ adults).

\begin{tabular}{|c|c|c|c|c|c|c|}
\hline \multirow{2}{*}{ Cultivar } & \multicolumn{6}{|c|}{ Callosobruchus Maculatus Population } \\
\hline & UM & $\mathrm{PH}$ & IT & MD-1 & MD-2 & MD-3 \\
\hline \multicolumn{7}{|c|}{ S. Stenocarpa um1 } \\
\hline & 27.3aA & $56.0 \mathrm{aC}$ & $63.7 \mathrm{bc}$ & $62.3 \mathrm{bBC}$ & $52.7 \mathrm{aBC}$ & $40.3 \mathrm{aAB}$ \\
\hline um2 & 37.7abA & $56.0 \mathrm{aA}$ & 51.3abA & 58.0abA & $52.3 \mathrm{aA}$ & $56.3 \mathrm{bcA}$ \\
\hline um3 & 44.3abAB & $45.0 \mathrm{aAB}$ & $34.3 \mathrm{aA}$ & $63.3 \mathrm{bc}$ & $57.7 \mathrm{aBC}$ & 46.3abAB \\
\hline um4 & $52.0 \mathrm{bA}$ & $48.3 \mathrm{aA}$ & $39.7 \mathrm{aA}$ & $62.0 \mathrm{bA}$ & $57.0 \mathrm{aA}$ & 48.0abA \\
\hline um5 & $30.7 \mathrm{aA}$ & 62.3aBC & 38.7aAB & $63.0 \mathrm{bC}$ & $65.0 \mathrm{aC}$ & 55.0abcBC \\
\hline \multicolumn{7}{|c|}{ V. Unguiculata } \\
\hline TVu 2027 (rc) & $29.0 \mathrm{aA}$ & $49.0 \mathrm{aBC}$ & 53.3abC & 35.7aAB & $60.7 \mathrm{aC}$ & $58.7 \mathrm{bcC}$ \\
\hline Ife Brown (sc) & 40.3abA & 46.0aAB & $\begin{array}{c}\text { 50.0abABC } \\
48.3 \mathrm{abAC}\end{array}$ & & $58.3 \mathrm{aBC}$ & $64.3 \mathrm{cC}$ \\
\hline $\begin{array}{l}\text { Mean (across all } \\
\text { cultivars) }\end{array}$ & $37.3 \mathrm{~A}$ & $51.8 \mathrm{BC}$ & $47.3 \mathrm{~B}$ & $56.1 \mathrm{C}$ & $57.7 \mathrm{C}$ & $52.7 \mathrm{BC}$ \\
\hline
\end{tabular}

$\mathrm{rc}=$ resistant control; $\mathrm{sc}=$ susceptible control; +see map of Nigeria: $\mathrm{UM}=\mathrm{Umuahia} ; \mathrm{PH}=$ Port Harcourt; IB = IITA Ibadan; MD1,2,3 = Maiduguri. Values followed by the same lowercase (columns) or uppercase (rows) letters are not significantly different at $\mathrm{P} \leq 0.05$ (Fisher's Protected

Table 2: Mean development time from egg to adult Callosobruchus maculatus from different localities in Nigeria+ kept on seeds of S. stenocarpa and Vigna unguiculata. $(\mathrm{n}=40)$.

\begin{tabular}{|c|c|c|c|c|c|c|}
\hline \multirow{2}{*}{ Cultivar } & \multicolumn{5}{|c|}{ Callosobruchus Maculatus Population } \\
\cline { 2 - 7 } & UM & PH IT & & MD-1 & MD-2 & MD-3 \\
\hline & $26.9 \mathrm{abcA}$ & $34.0 \mathrm{abcB}$ & $34.5 \mathrm{cB}$ & $26.8 \mathrm{aA}$ & $25.0 \mathrm{aA}$ & $36.1 \mathrm{cB}$ \\
\hline um2 & $26.9 \mathrm{abcA}$ & $29.5 \mathrm{abAB}$ & $34.9 \mathrm{cB}$ & $34.5 \mathrm{abB}$ & $25.3 \mathrm{abA}$ & $32.7 \mathrm{bcB}$ \\
\hline um3 & $27.7 \mathrm{bcB}$ & $31.0 \mathrm{abcC}$ & $34.2 \mathrm{cD}$ & $44.0 \mathrm{cE}$ & $25.7 \mathrm{abA}$ & $31.6 \mathrm{bC}$ \\
\hline um4 & $26.5 \mathrm{abA}$ & $26.2 \mathrm{aA}$ & $34.5 \mathrm{cC}$ & $40.0 \mathrm{bcD}$ & $25.0 \mathrm{aA}$ & $30.7 \mathrm{bB}$ \\
\hline um5 & $27.8 \mathrm{bcAB}$ & $36.5 \mathrm{bcCD}$ & $34.0 \mathrm{cC}$ & $43.0 \mathrm{cD}$ & $25.5 \mathrm{abA}$ & $33.2 \mathrm{bcBC}$ \\
\hline & & V. Unguiculata & & \\
\hline & $31.0 \mathrm{cAB}$ & $37.6 \mathrm{cB}$ & $27.9 \mathrm{bA}$ & $*$ & $30.0 \mathrm{cAB}$ & $31.6 \mathrm{bAB}$ \\
\hline TVu 2027 (rc) & $23.4 \mathrm{aB}$ & $26.1 \mathrm{aC}$ & $22.7 \mathrm{aA}$ & $26.9 \mathrm{aD}$ & $26.7 \mathrm{bD}$ & $26.6 \mathrm{aCD}$ \\
\hline Ife Brown (sc) & $27.0 \mathrm{~A}$ & $31.4 \mathrm{~B}$ & $32.0 \mathrm{~B}$ & $34.1 \mathrm{~B}$ & $26.2 \mathrm{~A}$ & $31.8 \mathrm{~B}$ \\
\hline Mean (across all cultivars) & & & & \\
\hline &
\end{tabular}

*no survivors; $\mathrm{rc}=$ resistant control; sc = susceptible control; +see map of Nigeria: UM = Umuahia; $\mathrm{PH}=$ Port Harcourt; IT = IITA Ibadan; MD1, 2, 3 = Maiduguri. Values followed by the same lowercase (columns) or uppercase (rows) letters are not significantly different at $\mathrm{P} \leq 0.05$ (Fisher's Protected LSD).

which took (37.6 days) $(\mathrm{F}=7.999$, d.f. $=5.99, \mathrm{p}=0.0001)$. All other populations had larval developmental times between 27.9-37.6 days but similar to the $\mathrm{PH}$ population (Table 2).

\section{Adult emergence}

The development time of UM \& MD-2 population was relatively short on $S$. stenocarpa (Table 2). However, daily emergence data revealed that only a few MD-2 individuals actually contributed to the population (Figure 2). In addition, survivorship to the adult stage on S. stenocarpa was high only in the UM population (Table 3 ). The daily emergence patterns of this population were also not similar on all the cultivars (Figure 2). All other beetle populations had a distinct emergence peak on Ife Brown within the first week. Most of the eggs that were laid on the seeds hatched and larvae penetrated the seeds. Therefore, suitability of the seeds for larval development (within-seed mortality of [29-35], rather than larval penetration into the seed played an important role. All beetle populations performed poorly on TVu 2027 compared to Ife Brown (Table 3), even though the IT and PH beetles were relatively more successful than others in developing on this resistant cultivar. Furthermore, although all MD populations appeared to be susceptible $(\mathrm{F}=13.307$, d.f. $=4,6, \mathrm{p}=0.0038)$ to $\mathrm{TVu} 2027$, MD-1 was the most sensitive and produced no adults (Table 3 ).



Figure 2: Daily emergence patterns of different populations of Callosobruchus maculatus on African yam bean (AYB) (Umuahia 1-5) and cowpea (rc and sc). The AYB cultivars [Umuahia 1-5] were from local markets in Umuahia; $r c=$ resistant control, $s c=$ susceptible control.

\section{Beetle progeny performance}

With a few exceptions, progeny from reciprocal crosses showed greater fitness than their parents on both S. stenocarpa and TVu 2027 for all variables recorded, with the exception of development time where progeny values were equal to, or higher than, those of the parents (Figure 3). Fitness of the progeny (percentage adult emergence and growth index) seemed to increase irrespective of the direction of the cross; also, the MD-1 population that produced no offspring from TVu 2027 (Table 3) did so when crossed with other beetle populations (Figure 3). Crosses involving females of $\mathrm{PH}$ and IT produced more adults than was the case from other crosses. The susceptible cultivar, Ife Brown, was suitable for the growth and development of the hybrids as well as the parents. The data are therefore not presented here.

\section{PCR-RAPD analysis}

Of the 60 random oligonucleotide primers (Operon Technologies sets H, I and Q) evaluated for their ability to prime PCR amplification of beetle genomic DNA, 50 resulted in only limited amplifications which were visualized in the gels as faint bands or smears. The remaining 10 primers adequately amplified the genomic DNA, giving reproducible RAPD amplification patterns with individual fragments that stained intensely (Figure 4). These primers were useful for detecting polymorphism among the beetle populations.

Table 3: Mean percentage emergence of adult Callosobruchus maculatus from different localities in Nigeria+ kept on seeds of S. stenocarpa and V. unguiculata cultivars. $(n=80)$.

\begin{tabular}{|c|c|c|c|c|c|c|}
\hline \multirow{2}{*}{ Cultivar } & \multicolumn{7}{|c|}{ Callosobruchus Maculatus Population } \\
\cline { 2 - 7 } & UM & PH & IT & MD-1 & MD-2 & MD-3 \\
\hline \multicolumn{7}{|c|}{ S. stenocarpa } \\
\hline um1 & $75.4 \mathrm{cE}$ & $0.5 \mathrm{aA}$ & $11.9 \mathrm{aD}$ & $4.1 \mathrm{aBC}$ & $1.2 \mathrm{aAB}$ & $10.6 \mathrm{abCD}$ \\
\hline um2 & $66.6 \mathrm{bcD}$ & $1.5 \mathrm{aA}$ & $10.9 \mathrm{aB}$ & $2.3 \mathrm{aA}$ & $3.9 \mathrm{aA}$ & $20.3 \mathrm{bC}$ \\
\hline um3 & $44.0 \mathrm{bcC}$ & $2.8 \mathrm{aA}$ & $16.6 \mathrm{aB}$ & $0.5 \mathrm{aA}$ & $3.4 \mathrm{aA}$ & $16.2 \mathrm{abB}$ \\
\hline um4 & $78.3 \mathrm{cD}$ & $4.3 \mathrm{aAB}$ & $14.8 \mathrm{aBC}$ & $0.9 \mathrm{aA}$ & $0.5 \mathrm{aA}$ & $19.3 \mathrm{bC}$ \\
\hline um5 & $66.2 \mathrm{bcD}$ & $1.0 \mathrm{aA}$ & $12.8 \mathrm{aBC}$ & $3.7 \mathrm{aAB}$ & $2.9 \mathrm{aA}$ & $22.9 \mathrm{bC}$ \\
\hline & & V. unguiculata \\
\hline TVu 2027 (rc) & $4.4 \mathrm{aB}$ & $29.7 \mathrm{bC}$ & $35.8 \mathrm{bC}$ & $0.0 \mathrm{aA}$ & $1.6 \mathrm{aAB}$ & $4.0 \mathrm{aB}$ \\
\hline Ife Brown (sc) & $71.8 \mathrm{cA}$ & $84.5 \mathrm{cA}$ & $70.1 \mathrm{cA}$ & $78.1 \mathrm{bA}$ & $78.9 \mathrm{bA}$ & $77.0 \mathrm{cA}$ \\
\hline Mean (across all cultivars) & $58.1 \mathrm{C}$ & $17.7 \mathrm{AB}$ & $24.7 \mathrm{~B}$ & $12.8 \mathrm{~A}$ & $13.2 \mathrm{~A}$ & $24.3 \mathrm{~B}$ \\
\hline
\end{tabular}

$\mathrm{rc}=$ resistant control; sc = susceptible control.; +see map of Nigeria: $\mathrm{UM}=$ Umuahia; $\mathrm{PH}=$

Port Harcourt; IT = IITA Ibadan; MD1,2,3 = Maiduguri. Values followed by the same

lowercase (columns) or uppercase (rows) letters are not significantly different at $\mathrm{P} \leq 0.05$ (Fisher's Protected LSD).

Citation: LEN Jackai, G Thottappilly, HO Sintim, TI Ofuya and BN Dingha (2021)Biological and Molecular Evidence for the Existence of Bruchid Ecotypes in the Nigerian Cowpea Ecosystem: Environ Sci Ecol Curr Res 2: 1030 


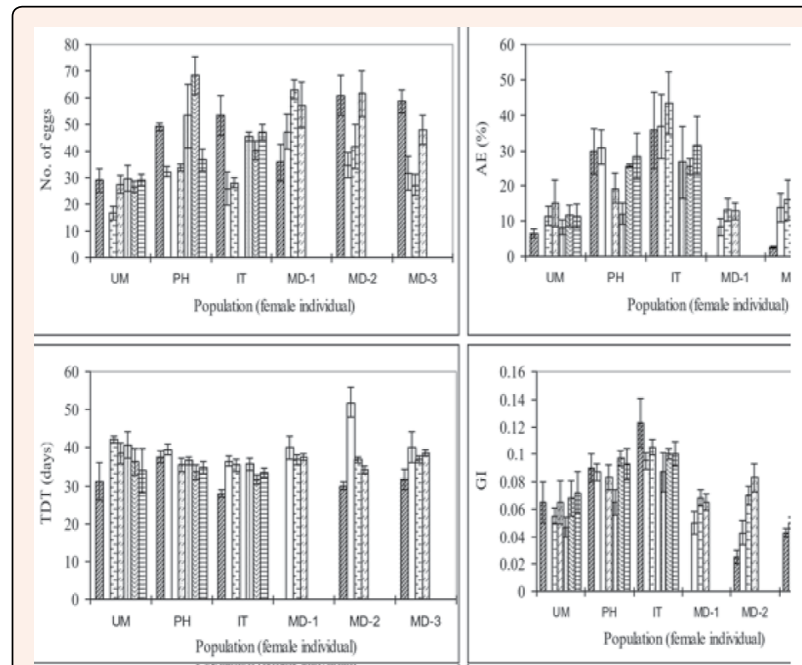

Figure 3: Egg deposition, development time, adult emergence and suitability index of progeny from reciprocal crosses between different populations of Callosobruchus maculatus kept on cowpea cultivar TVu 2027 (resistant to the IITA population). (IT = IITA Ibadan; PH = Port Harcourt; UM = Umuahia; MD-1, 2, 3 = Maiduguri).

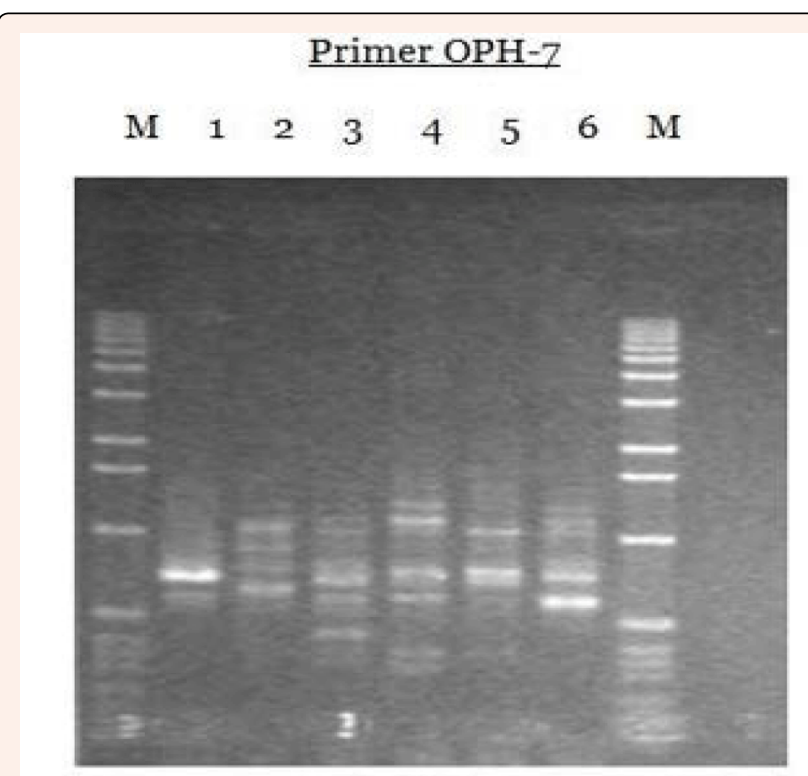

Figure 4: RAPD electrophoretic profiles of genomic DNA from eight beetle populations of Callosobruchus maculatus amplified with primer $\mathrm{OPH}-7$. Lane $\mathrm{M}=1 \mathrm{~kb}$ DNA size marker. $1=\mathrm{IT}, 2=\mathrm{PH}, 3=\mathrm{UM}, 4=\mathrm{MD}(1), 5=\mathrm{MD}(2), 6=\mathrm{MD}(3)$.

Based on cluster analysis, the overall genetic relationship among the investigated beetles representing different populations is illustrated (Figure 5). Based on this, the insects were categorized into 6 different lineages with the IT and MD2 populations showing the closest relationship (50\% similarity) and PH being the most distant from the Ibadan (IT) population. The results also show close relationship between the three MD populations, as well as between $\mathrm{PH}$ and UM populations.

\section{Discussion}

This study suggests that discrete populations of C. maculatus are distinguishable from the study localities used in Nigeria. Based on the demographic responses, particularly in beetle development and survival on S. stenocarpa and a contrasting variety of $V$. unguiculata (TVu 2027), of these populations it appears as though "ecotypes" or ecologically discrete populations of this insect occur in Nigeria but were not reproductively isolated. The differences between the bruchid populations were obvious in some cases. For example, the UM beetles developed well on S. stenocarpa while others did rather poorly. Along with all three MD populations, UM did not find the resistant control, TVu 2027, suitable for development. The rather impressive performance of UM beetles on S. stenocarpa could be the result of co-evolution. The African yam bean is cultivated for human consumption in Umuahia and other parts of southeastern Nigeria. It is therefore conceivable that $C$. maculatus whose principal host is cowpea, fortuitously colonized S. stenocarpa and over time disarmed the seed lectins $[23,24,38]$, in the new host in the "UM" region of Nigeria. A great deal of variation in the response of $C$. maculatus to feeding on $S$. stenocarpa cultivars has been reported elsewhere, where it develops well on some [30] and not at all on others [23]. The assumption has always been that the same insect genotype is the same was used in these tests. The possibility of polymorphism in this bruchid had not been previously considered or investigated. Sphenostylis stenocarpa is not a common host of $C$. maculatus, except possibly in the eastern and 'middle' belt of Nigeria where production of this crop seems to be concentrated [39,25]. It is likely that genes for vigour or fitness exist at a rather high frequency within the insect population found associated with the crop. It is also possible that the UM and PH ecotypes had somehow encountered the resistant genes of TVu 2027 (originally from Sokoto in the northwest of Nigeria) [9], which may have spread throughout the cowpea belt of northern Nigeria. Although not grown in the eastern part of Nigeria, TVu 2027 is probably marketed and stored in the southern parts of the country along with other varieties of cowpea. Although there are established trade routes, movement of food commodities within Nigeria can sometimes be unpredictable. Therefore, although more cowpea may be moved annually from northeast to southeast than from northwest to southeast, it is likely that some TVu 2027 found its way to the $\mathrm{PH}$ area through the vibrant commercial traffic of western dwellers and other traders who visit or live in Port Harcourt and its vicinity. Even so, this would, in part, only explain in part the relatively good performance of $\mathrm{PH}$ on this cultivar (adult emergence approximately 30 $\%$ ), and not explain the poor performance of the UM beetle population (adult emergence $6.7 \%$ ). The possible pre-adaptive occurrence of genes for vigor within the $\mathrm{PH}$ population, or inadvertent introductions of IT genes from the western part of the country to the Port Harcourt area, cannot be discounted. The ability of PH and UM beetles to survive on $S$. stenocarpa seemed to be crucial in their genetic separation from the other beetle populations. Poor performance of the MD populations on S. stenocarpa and cowpea cultivar TVu 2027 can be explained by their relative isolation. Despite what appears to be a rather high fecundity, the actual adult recruitment into the population reared on these accessions was extremely low, especially in MD-1 and MD-2. This may be explained by the geographic isolation of these insects for long periods from eastern Nigeria where $S$. stenocarpa is grown, and from the northwest of the country where TVu 2027 is grown. These two sections of Nigeria are separated from each other and the western part by extensive stretches of unstable savanna grasslands and transition forests. Alternatively, it may be assumed that there has been little gene flow (movement of resistance genes) to these areas. Consequently, the already isolated C. maculatus populations have not encountered the genes in TVu 2027 and S. stenocarpa. The performance of IT and PH populations has a different significance. Although development time on TVu 2027 was comparable among all populations, percentage adult emergence and growth index values were several-fold

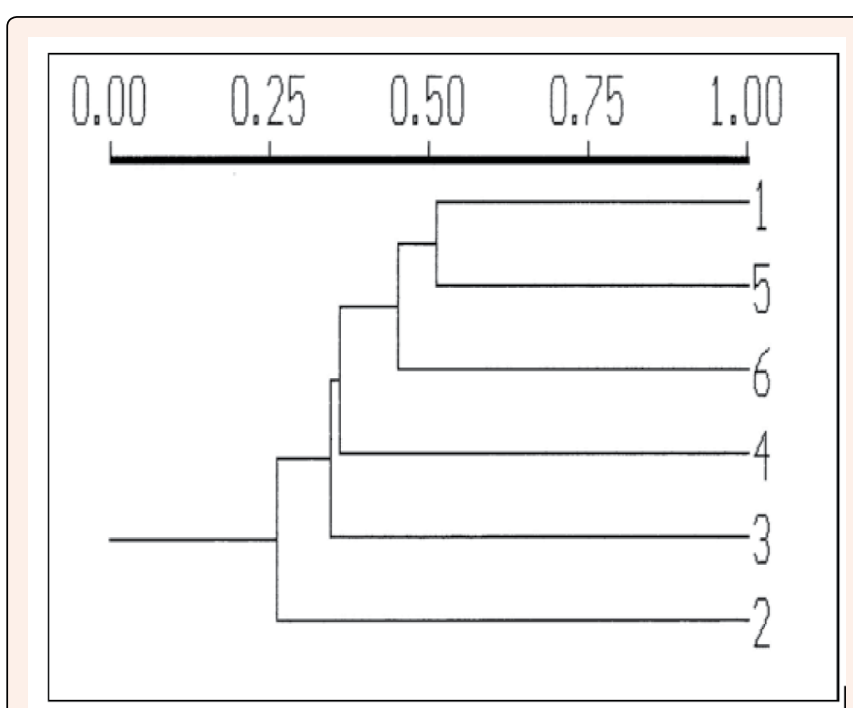

Figure 5: Genetic relationship of representative individuals of populations of Callosobruchus maculatus from different parts of Nigeria. (1 = IT [IITA Ibadan]; $2=\mathrm{PH}$ [Port Harcourt]; 3 = UM [Umuahia]; 4-6 = MD-1, 2, 3 [Maiduguri]). 
higher in the IT and PH populations. In agreement with previous workers [12], of all parameters studied, percentage adult emergence gave the best discrimination between populations [12]. we have reported much higher emergence values for the IT population, but this difference could be as a result of the constant out-crossing of the IITA (IT) (stock) population with "wild" insects. This process would likely reduce the gene frequency for fitness in the resident population. However, despite this out-crossing, the population has recently shown increased fitness on TVu 2027 [23].

The possibility of ecotype or biotype formation (i. e. increased frequency of genes for virulence on $\mathrm{TVu}$ 2027) upon the application of intense selection pressure has been long suspected $[40,15,41,42]$. In addition, studies at Purdue University using beetle populations from different parts of the world have confirmed this [27. Differences among the populations are further supported by the PCR-RAPD analysis which shows that the IITA ecotype (IT-1) had the least similarity to the PH and UM ecotypes, a fact clearly demonstrated in their better survival on S. stenocarpa. The PH ecotype stood clearly different from all other groups to which it had only $25 \%$ similarity. The MD ecotypes were intermediate, and although closely related, the MD populations appear to be a highly heterogeneous group. This may be explained in part by the possible fortuitous contamination by beetles from neighbouring Cameroon, which has an active cowpea trade with Nigeria. At $50 \%$ level of similarity, all three MD populations are in different lineages. Whether this explains the extreme sensitivity of the MD-1 ecotype to TVu 2027 or not remains to be verified. Since all populations cross-mated readily, we assume that they are the same species. Performance of the beetle progeny was indicative of hybrid vigor with potential to overcome resistance barriers in cowpea. Unfortunately, logistic difficulties precluded including S. stenocarpa in this aspect of our study. Nevertheless, better progeny performance on TVu 2027, especially with regard to adult emergence, is of ecological interest. Firstly, it is quite possible for the different beetle populations to be inadvertently interbred through the activity of traders from different parts of the country or from neighboring countries such as Cameroon. Once this happens, there would occur an increase in the frequency of the genes for counteracting the resistance of TVu 2027 in the population [40]. This is indicated by the superior performance of the hybrids on $\mathrm{TVu} 2027$ (Figure 3), and should indeed be cause for concern to cowpea breeders in the region. Given the foregoing scenario, a different set of resistance genes (possibly a cocktail of genes) would be required to protect resistant varieties derived from either TVu 2027 or S. stenocarpa. The causes of poor development of this insect on S. stenocarpa are unknown, although preliminary results from past work at IITA suggest that both primary and secondary compounds may be involved. Our findings are indicative of the existence of beetle ecotypes with genes for virulence to $S$. stenocarpa and to a lesser extent cowpea cultivar TVu 2027. Since both inter-, and intra-, specific variation in the genus Callosobruchus exist within and outside Nigeria, a systematic study of bruchid populations is necessary in order to streamline the deployment of resistant cowpea cultivars in the region. This would help to monitor and map the occurrence of genes enabling bruchids to overcome resistance mechanisms, and accordingly guide breeding efforts [43-62].

\section{Acknowledgments}

The authors gratefully acknowledge the assistance of various colleagues who reviewed the manuscript and made useful suggestions.

\section{References}

1. Singh SR (1977) Cowpea Cultivars Resistant to Insect Pests in World Germplasm Collection. Tropical Grain Legume Bulletin 9: 3-7.

2. Caswell GH (1981) Damage to stored Cowpea in the Northern part of Nigeria. Samaru Journal of Agricultural Research 1: 11-19.

3. Seck D (1993) Resistance to Callosobruchus maculatus F (Col Bruchidae) in some Cowpea Varieties from Senegal. Journal of Stored Product Research 29: 49-52.

4. Ali SM, Mahgoub SM, Hamed MS, Gharib MSA (2004) Infestation potential of Callosobruchus chinensis and C. maculatus on certain broad bean seed varieties. Egypt Journal of Agriculture Research 82: 1127-1135.

5. Southgate BJ (1978) The Importance of the Bruchidae as Pests of Grain Legumes, the Distribution and Control. (In:) Singh SR, Van Emden HF, Taylor TA (Eds.), Pests of Grain Legumes: Ecology and Control, Academic Press, London Ppp. 219-229.

6. Southgate BJ (1979) Biology of the Bruchidae. Annual Review of Entomology 24: 449-473.

7. Decelle J (1981) Bruchidae related to Grain Legumes in the Afro-Tropical area. Series Entomologica 19: 193-197.

8. Adugna H (2006) On-Farm Storage Studies in Eritrea. African Journal of Biotechnology 5: 1537-1544.
9. Singh SR, Jackai LEN (1985) Insect Pests of Cowpeas in Africa: their Life Cycle, Economic Importance and Potential for Control. (In:) Singh SR \& Rachie, KO (Eds.) Cowpea Research, Production and Utilization, John Wiley \& Sons, Chichester, USA, Ppp. 217-231.

10. Ofuya TI, Bamigbola KA (1991) Damage Potential, Growth and Development of the Seed Beetle, Callosobruchus maculatus (Fabricius.) (Coleoptera: Bruchidae) on some Tropical Legumes. Tropical Agriculture (Trinidad) 68: 33-36.

11. Adedire CO, Akinneye JO (2003) Biological Activity of Three Marigold, Tithonia diversifolia, on Cowpea Seed Bruchids, Callosobruchus maculatus (Coleoptra: Bruchidae). Annals of Applied Biology 144: 185-189.

12. Dick KM, Credland PF (1986) Changes in the response of Callosobruchus maculatus (Coleoptera: Bruchidae) to a Resistant Variety of Cowpea. Journal of Stored Product Research 22: 227-233.

13. Credland PF (1990) Biotype variation and Host range in Bruchids: causes and effects in the Evolution of Bruchid Pests (In:), K Fuji, Gatehouse, AMR, Johnson CD Mitchell, R Yoshida, T. (Eds.), Bruchids and Legumes: Economics, Ecology and Coevolution, Kluver Academic, The Netherlands Ppp. 271-287.

14. Giga DP, Kadzere I, Canhao J (1993) Bionomics of Four Strains of Callosobruchus rhodesianus (Pic) (Coleoptera: Bruchidae) infesting different Food Legumes. Journal of Stored Product Research 29: 19-26.

15. Dick KM, Credland PF (1986) Variation in the response of Callosobruchus maculatus (F.) to a Resistant Variety of Cowpea. Journal of Stored Product Research 22: 43-48.

16. Hall A, Cisse N, Thiaw S, Elawad HOA, Ehlers JD, Ismail AM, Fery RL (2003) Development of cowpea cultivars and germplasm by the Bean/Cowpea CRSP. Field Crop Research 82: 103-134.

17. Price PW (1975) Insect Ecology. John Wiley and Sons, New York, USA.

18. Appleby JH, Credland PF (2003) Variation in Responses to Susceptible and Resistant Cowpeas among West African Populations of Callosobruchus maculatus (Coleoptera: Bruchidae). Journal of Economic Entomology 96: 489-502.

19. Guedes NMP, Guedes RNC, Campbell JF, Throne JE (2010) Contest behaviour of maize weevil larvae when competing within seeds. Anim Behav 79: 281-289.

20. Mitchell R (1991) The Traits of a Biotype of Callosobruchus maculatus (F.) (Coleoptera: Bruchidae) from South India. Journal of Stored Product Research 27: 221-224.

21. Beck CW, Blumer LS (2011) A Handbook on Bean Beetles, Callosobruchus maculatus. National Science Foundation.

22. Redden RJ, Dobie P, Gatehouse AMR (1983) The inheritance of seed resistance to Callosobruchus maculatus F. in cowpea (Vigna unguiculata L. Walp.) I Analysis of parental, F1, F2, F3, and backcross seed generations. Australian Journal of Agricultural Research 34: 681-695.

23. Machuka J, Okeola O, Chrispeels MJ, Jackai LEN (2000) The African yam bean seed lectin affects the development of the cowpea weevil but does not affect the development of larvae of the legume pod borer. Phytochemistry 53: 667-674.

24. Sadeghi A, Van Damme EJM, Peumans WJ, SMAGGHE G (2006) Deterrent activity of plant lectins on cowpea weevil Callosobruchus maculatus (F.) oviposition. Phytochemistry 67: 2078-2084.

25. DUKE JA (1981) Handbook of Legumes of World Economic Importance. Plenum Press. New York, USA Ppp. 345.

26. Ikhajiagbe B, Mgbeze GC, Erhenhi H (2009) Growth and yield responses of Phenostylis stenocarpa (Hochst Ex. A. Rich) Harms (African yam bean) Harms to phosphate enrichment of soil. Africa Journal of Biotechnology 8: 641-643.

27. Shade RE, Kitch LW, Mentzer P, Murdoch L (1996) Selection of a Cowpea Weevil (Coleoptera: Bruchidae) Biotype virulent to Cowpea Weevil-Resistant Landrace TVu 2027. Journal of Economic Entomology 89: 1325-1331.

28. Miyatake T, Matsumura F (2004) Intra-specific variation in female remating in Callosobruchus chinensis and Callosobruchus maculatus. Journal of Insect Physiology 50: 403-408. 
29. Harano T, Fujisawa, M Miyatake, T (2006) Effect of oviposition substrate on female remating in Callosobruchus chinensis (Coleoptera: Bruchidae). Applied Entomology \& Zoology 41: 569-572.

30. Ofuya TI, Credland PF (1995) Responses of Three Populations of the Seed Beetle, Callosobruchus maculatus (Fabricius) (Coleoptera: Bruchidae) to Seed Resistance in Selected Varieties of Cowpea, Vigna unguiculata (L.) Walp. Journal of Stored Product Research 31: 17-27.

31. Williams CL, Goldson SL, Baird DB, Bullock DW (1994) Geographical Origin of an introduced Insect Pest, Listronotus bonariensis (Kuschel), determined by RAPD Analysis. Heredity 72: 412-419.

32. Livak KJ (1984) Organization and Mapping of a Sequence on the Drosophila melanogaster $\mathrm{X}$ and $\mathrm{Y}$ chromosome that is transcribed during Spermatogenesis. Genetics 107: 611-634.

33. Dowdy AK, Mcgaughey, WH (1996) Using Random Amplified Polymorphic DNA to differentiate Strains of the Indian Meal Moth (Lepidoptera: Pyralidae) Environmental Entomology 25: 396-400.

34. De Leon JH, Jones WA (2004) Detection of DNA polymorphisms in Homalodisca coagulata (Homoptera: Cicadellidae) by polymerase chain reaction-based DNA fingerprinting methods. Annals of the Entomological Society of America 97: 574585

35. Howe RW (1971) A Parameter for expressing the Suitability of an Environment for Insect Development. Journal of Stored Product Research 7: 63-65.

36. Guthrie PAL, Magill CW, Frederiksen RA, Odvody GN (1992) Random Amplified Polymorphic DNA Markers: a System for identifying and differentiating Isolates of Colletotrichum graminicola. Phytopathology 82: 832-835.

37. Sokal RR, Rohlf RF (1981) Biometry. Freeman, New York, USA.

38. Sankara F, Dabire LCB, Dugravot S, Cortesero AM, Sanon A (2010) Evolution of host acceptability and suitability in Callosobruchus maculatus (Coleoptera: Bruchidae) developing on an occasional host: importance for pest status prediction. International Journal of Tropical Insect Science 30:11-18.

39. Okigbo BN (1973) Introducing the Yam Bean, Sphenostylis stenocarpa (Hochst ex. A Rich) Harms. Proceedings of the First IITA Grain Legumes Improvement Workshop 2: 224-237

40. Pimentel D, Glenister C, Fast S, Gallahan D (1984) Environmental Risks of Biological Pest Controls. Oikos 42: 283-290.

41. Fox CW, Bush ML, Messina FJ (2010) Biotypes of the seed beetle Callosobruchu maculatus have differing effects on the germination and growth of their legume hosts. Agricultural and Forest Entomology 12: 353-362.

42. Tarver MR, Shade RE, Tarver RD, Liang Y, Krishnamurthi G, et al. (2006) Use of micro-CAT scans to understand cowpea seed resistance to Callosobruchus maculatus. Entomologia Experimentalis et Applicata 118: 33-39.

43. Black WC, Duteau NM, Puterka GJ, Nechols JR, Pettorini JM (1992) Use of the Random Amplified Polymorphic DNA Polymerase Chain reaction (RAPD-PCR) to detect DNA Polymorphisms in Aphids. Bulletin Entomological Research 82: 151159

44. Dobie P (1981) The use of Resistant Varieties of Cowpea (Vigna unguiculata) to reduce losses due to Post-Harvest attack by Callosobruchus maculatus. (In:) Labeyrie, V. (Ed.) The Ecology of Bruchids attacking Legumes (Pulses), Junk, The Hague, Netherlands Ppp. 185-192.

45. Gatehouse AMR, Gatehouse JA, Dobie P, Kilminster AM, Boulter D (1979) Biochemical Basis of Insect Resistance in Vigna unguiculata. Journal of Science Food and Agriculture 30: 948-958.
46. Giga DP, Mith RH (1983) Comparative Life History Studies of Four Callosobruchus Species infesting Cowpeas with Special Reference to Callosobruchus rhodesianus (Pic). (Coleoptera: Bruchidae). Journal of Stored Product Research 19: 189-198.

47. Gould F (1978) Predicting the future resistance of crop varieties to pest populations: a case study of mites and cucumber. Environmental Entomology 7: 622-626.

48. Jaccard P (1901) Etude Comparative de la Distribution Florale dans une Portion des Alpes et des Jura. Bulletin de la Societé Vaudoise Science et Nature 37: 547-579.

49. (1908) Nouvelles Recherches sur la Distribution Florale. Bulletin de la Societé Vaudoise Science et Nature 44: 223-270.

50. Kitch LW, Ntoukam, Shade RE, Wolfson JL, Murdock LL (1992) A Solar Heate for disinfesting Stored Cowpeas on Subsistence Farms. Journal of Stored Product Research 28: 261-267.

51. Kitch LW, Shade RE, Murdock LL (1991) Resistance to the Cowpea Weevil (Callosobruchus maculatus) Larva in Pods of Cowpea (Vigna unguiculata). Entomologia Experimentalis et Applicata 60: 183-191.

52. Mbata GN (1993) Evaluation of Susceptibility of Varieties of Cowpea to Callosobruchus maculatus (F.) and Callosobruchus subinotatus (Pic). (Coleoptera: Bruchidae). Journal of Stored Product Research 29: 207-213.

53. Mendel Z, Nestel D, Gafny R (1994) Examination of the Origin of the Israel Population of Matsucoccus josephi (Homoptera: Matsucoccidae) using Random Amplified Polymorphic DNA Polymerase Chain Reaction Method. Annals Entomological Society of America 87: 165-169.

54. Messina FJ, Jones JC, Mendenhall M, Amberleigh Muller A (2009) Genetic Modification of Host Acceptance by a Seed Beetle, Callosobruchus maculatus (Coleoptera: Bruchidae). Annals of Entomological Society of America 102: 181-188.

55. Nwanze K, Horber E (1976) Seed Coats of Cowpeas affect Oviposition and Larval Development of Callosobruchus maculatus (F.) Environmental Entomology 5: 213218.

56. Puterka GJ, Black IV, STEINER WC, BURTON RL (1993) Genetic Variation and Phyllogenic Relationships among World-wide Collections of the Russian Wheat Aphid, Diuraphis noxia (Mordvilko), inferred from Allozyme and RAPD-PCR Markers. Heredity 70: 604-618.

57. Singh SR (1980) Biology of Cowpea Pests and Potential for Host Plant Resistance. In: Harris, MK (Edn.), Biology and Breeding for Resistance to Arthropods and Pathogens in Agricultural Plants. 398-421.

58. Singh, SR, Jackai, LEN, Dos Santos JHR, Adalla CB (1990) Insect Pests of Cowpeas In: Singh, SR (Edn.), Insect Pests of Tropical Legumes. 91-156.

59. Smith RH, LESSELS CM (1984) Oviposition, Ovicide and Larval Competition in Granivorous Insects. In Sibley, R.M \& Smith, R.H. (Eds.) Behavioral Ecology: Ecological Consequences of Adaptive Behaviour, Symposium, British Ecological Society, Blackwell, London. 432-448.

60. Sneath PH, Sokal RR (1973) Numerical Taxonomy. The Principles and Practice of Numerical Classification, WH Freeman \& Co, San Francisco, USA.

61. Xavier Filho J, Campos FAP, ARY MB, Silva CP, Calvaho MMH, et al. (1989) Poor Correlation between the Levels of Proteinase Inhibitors found in some Seeds of Different Cultivars of Cowpea (Vigna unguiculata) and the Resistance/Susceptibility to Predation by Callosobruchus maculatus. Journal of Agriculture and Food Chemistry 37: 1139-1143

62. Zhu K, Huesing JE, Shade RE, Murdock LL (1994) Cowpea Trypsin Inhibitor and Resistance to Cowpea Weevil (Coleoptera: Bruchidae) in Cowpea Variety 'TVu 2027. Environmental Entomology 23: 987-991. 